Strategic institutional approaches to graduate employability: Navigating meanings, measurements, and what really matters

Professor Ruth Bridgstock ${ }^{\mathrm{a}}$ and Associate Professor Denise Jackson ${ }^{\mathrm{b} *}$

${ }^{a}$ Centre for Learning Futures, Griffith University, Brisbane, Australia r.bridgstock@griffith.edu.au, ORCID: 0000-0003-0072-2815

${ }^{b}$ School of Business and Law, Edith Cowan University, Joondalup, Australia d.jackson@ecu.edu.au, ORCID: 0000-0002-7821-3394 


\title{
Strategic institutional approaches to graduate employability: Navigating meanings, measurements, and what really matters
}

\author{
Abstract \\ Despite ongoing efforts by universities, challenges and tensions continue to exist in academic \\ discourse, policy and practice around graduate employability. These factors militate against \\ the sector's capacity to prepare learners for life and the world of work, because they promote \\ unclear, and sometimes counterproductive and competing, courses of action. This article \\ suggests that higher education institutions' approaches to graduate employability reflect at \\ least three concurrent aims. The aims relate to: (i) short-term graduate outcomes; (ii) \\ professional readiness; and (iii) living and working productively and meaningfully across the \\ lifespan. The commitment to each of these aims is often tacit and ill-defined, and varies \\ within as well as between institutions, and over time. This article attempts to navigate a \\ productive path through the multiple aims and agendas in graduate employability, along with \\ the definitional and measurement challenges, to identify pragmatic, workable approaches for \\ universities. It suggests principles for the development of more effective institutional \\ employability strategies.
}

\section{Keywords}

Graduate employability, graduate outcomes, university policy, graduate attributes, professional accreditation

This work was supported by Graduate Careers Australia under its Graduate Research Program. 


\section{Introduction}

Examination of the history of universities shows that they have long contributed to the economies and societies in which they are located, through the creation and sharing of knowledge. This sharing of knowledge includes the graduation of students with capabilities that add value to their economic and social contexts (Boden \& Nedeva, 2010). Until fairly recently, graduates of higher education could be confident of obtaining professional employment afterwards, particularly in public service.

However, over the last thirty years, the role of universities has come under increasing scrutiny, with a tighter coupling of educational experiences to economic needs around the world (Smith et. al., 2018). Knowledge and skills have become accepted as drivers of growth in advanced 'knowledge economies' (Brown, Hesketh \& Williams, 2004), and as such governments and employer have demanded evidence of the human capital value and effectiveness of university education. At the same time, universities have become corporatised, with imperatives around competition and efficiency, and also massified, with far greater enrolment numbers than ever before. Massification has been linked to social justice agendas via widening participation and increased access of diverse learners to the equalising effects of education (Stevenson, Clegg \& Lefever, 2010). However, the biggest underpinning of massification of higher education is the move to educate more people who can then contribute to the economy as high value workers and consumers.

\section{Graduate employability: Continuing definitional challenges}

While scholars debated ideas relating to employability as early as the 1930 s (e.g., Clark, 1930), the agenda started to gather momentum in the 1990s, as a direct consequence of the evolving role of the university as producer of human capital (Harvey, 2000). Thus, contemporary definitions of graduate employability tend to be underpinned by human capital theory (Becker, 1964), focussing on the individual possession of skills, knowledge and other 
attributes acquired through university education that enable individuals to secure and maintain employment (e.g., Hillage \& Pollard, 1998). These definitions have been criticised for being nearly tautologous, and for overlooking an important additional range of individual influences on employability, such as social and cultural capital, and identity (Jackson \& Bridgstock, 2018; Tomlinson, 2017). Cultural capital relates to students' signals of 'good fit' and cultural alignment with the profession and workplace. Social capital refers to their professional relationships and networks and the 'who you know' elements of career building. Identity is a central underpinning factor to individual employability, relating to concepts and narratives students have about themselves, their chosen profession and career, and their broader lives.

A further problem with definitions that emphasise possession of skills to secure employment is that in focussing on employment outcomes they tend to conflate the effects of educational processes with the impact of 'demand side' factors on employment, such as the structure of the labour market, and competition for graduate level work (Holmes, 2001; McQuaid \& Lindsay, 2005). Some of the strongest influences on full-time graduate employment relate to the local graduate labour market and the reputation of the institution rather than educational factors (Karmel \& Carroll, 2016). Thus, the reality is that a graduate can possess advanced level professional skills and knowledge in a field, but may still be more challenged than others in obtaining a job role in their field of interest if (for instance): visa conditions limit their capacity to work; if they lack the confidence to apply their skills; if there is a high level of competition for roles in their field; if they have a disability; if they are unable to access the 'hidden' job market through their social networks; if they went to a university with comparatively lower reputational capital, or if they live in a region with high structural employment (Jackson \& Bridgstock, 2018). 


\section{Strategies to foster employability}

Most universities employ a range of employability strategies (Farenga \& Quinlan, 2016), and this varies by institution and also within institution by discipline and degree program. Skillsbased employability strategies have focussed on the development of disciplinary skills required for professional practice within the curriculum, along with generic / transferable skills such as teamwork and problem-solving, which are applicable and useful across multiple employment contexts (Clanchy \& Ballard, 1995). These are underpinned by a range of desirable qualities, such as resilience, creativity and proactiveness (Yorke \& Harvey, 2005). Many universities around the world have published statements on graduate attributes, which list the capabilities that they aim to develop in their students (Barrie, 2007; Kalfa \& Taska, 2017). In the last few years, educators have recognised the importance of strong career management skills to graduate employability (Bridgstock, 2009), and in many universities there has been a movement of career development learning from the co-curricular space to inside degree programs (Bridgstock, Grant-Iramu \& McAlpine, in-press). In an overcrowded and competitive graduate labour market, Employability Award schemes have been developed by some universities to recognise and promote the co- and extra-curricular experiences of their graduates, as a means of differentiation (Farenga \& Quinlan, 2016).

The traditional role of higher education centres on knowledge and skills, but in recent years many universities have started to move to affect many of the other influences on graduate employability. One way is through creating labour market opportunities, either directly (such as through employing its own students and graduates), or through being an 'entrepreneurial university' - that is, by building the economic capacity, and thus the employment capacity, of a local region through research-based innovation, knowledge exchange, and direct commercial action (Schulte, 2004). Many universities have their own job centres and recruitment agencies, the remit for which is finding their students and 
graduates jobs; some of these focus their activities particularly on students from diversity groups who can be disadvantaged in the jobs market. Student entrepreneurship programs and incubators aim to support students to create their own employment. Careers fairs, industry networking events, industry mentoring schemes, and work integrated learning opportunities (such as placements and internships) are strategies that build students' social capital and professional networks, as well as their skills.

This article takes as its starting point that universities tend to engage with employability conceptually and in terms of desired outcomes in three main ways. The three employability aims that universities adopt are suggested to be: (i) short-term graduate employment outcomes; (ii) professional readiness; and (iii) living and working productively and meaningfully across the lifespan. This article argues that the three aims are pursued concurrently by universities, with different emphases by institution and degree program. Some employability strategies contribute to the achievement of multiple employability aims, but strategies can also compete for resourcing and space in the curriculum. Universities do not necessarily differentiate between the aims explicitly, or adopt a deliberate balance between them in deciding upon strategy. The next section of this article considers each of the employability aims in turn, followed by reflecting upon what a more considered approach to institutional employability strategy - balancing performative, institutional, professional and individual student imperatives in productive ways - might entail.

\section{Employability as short-term graduate employment outcomes}

In many countries, governments have established university key performance indicators for graduate employability that focus on graduates' full-time employment a few months after course completion (Jackson \& Bridgstock, 2018). For instance, in Australia, the percentage of recent graduates who have managed to secure a full-time role of any type, along with their salary levels, is presented in the Quality Indicators of Learning and Teaching website by 
university and disciplinary area. In addition, there now exist several 'league tables' that incorporate graduate employment outcomes (such as the Times Higher Education's Global University Employability Ranking) and benchmark institutional performance. These published statistics are considered a proxy indicator for employability, and are used by prospective students and their parents, along with other ratings such as student satisfaction and course quality, to gauge institutional success and inform study choices. With moves towards basing government funding of higher education institutions on graduate employment outcomes in both Australia and the United Kingdom, the full-time employment indicator has become a powerful focus for many universities.

The fact that the proportion of graduates in short-term graduate employment is the key (and sometimes sole) measured indicator of graduate employability means that university leadership can set summative outcome targets for their employability interventions in terms of desired increases in percentage full-time graduate employment (Hazelkorn, 2015). In reality, as previously discussed in this article, there are a number of influences on graduate employment that have been demonstrated empirically to have greater impact on short-term graduate employment than educational interventions, such as the state of the local labour market, and the reputation of the university (Karmel \& Carroll, 2016). Ultimately this means that the impact of educational interventions on percentage full-time employment is likely to be somewhat limited.

The use of short-term employment outcomes as an indicator of employability has appeal partly because many students enter higher education seeking 'a good job' at the end of their degrees (Tomlinson, 2007). Amid increasing student fees for degree programs, many students are understandably seeking an immediate and tangible return on their investment. However, in the context of a massified higher education system and many more graduates 
than ever before, competition for a finite number of graduate level roles is also far greater than previously.

Measuring graduate employability using short-term graduate employment outcomes is also problematic on a number of other grounds. For instance, graduates with 'non-vocational' degrees, that is degrees that are not associated with one specific professional outcome, may take more time to transition to the workforce, and therefore may seem to be employable than their peers. Further, in some industry sectors such as the creative industries and information technology, the prevalence of project-based and entrepreneurial ways of working (Piperopolous, 2012) means that employability as full-time employment may not ever be a useful measure.

Graduate outcome measures also seem to operate somewhat at odds with future ways of working and building a productive career across all industry sectors. Graduates can increasingly expect to hold multiple job roles, including on a self-employment basis, and recurrently seek or create work (Committee for Economic Development of Australia [CEDA], 2015; Foundation for Young Australians, 2018). Self-employment and 'portfolio' ways of working involving multiple concurrent or overlapping work roles will become more common for knowledge workers due to structural labour market changes and the further rise of the 'gig' economy, along with digital influences on work such as automation and artificial intelligence (Bakhshi et. al., 2017).

We have elsewhere (Jackson \& Bridgstock, 2018, in press) presented arguments for the widening of short-term measures of graduate employability to include subjective measures incorporating graduates' own aims and goals, and recognising the different ways that they can add value through their work and other activities, and deepening of measures to include outcomes beyond initial labour market experiences. Some recent changes to measures of graduate outcomes in the United Kingdom and Australia have started to incorporate 
indicators of employer satisfaction with graduate employee work (Social Research Centre 2019a,) and measures of perceived underemployment and overqualification. Longitudinal surveys have also recently become a feature of graduate employability measurement in the United Kingdom and Australia, including repeated survey measures of employment up to 3 years post-course completion (HESA, 2018; Social Research Centre, 2019b).

Nonetheless, graduate employability as measured by short-term employment outcomes continues to be the single preeminent indicator that is used to gauge performance. Institutional employability strategies that target short term outcomes include those that seek to influence the graduate labour market and job opportunities for graduates directly (such as recruitment and job placement activities, employing its own students, and careers fairs), along with interventions that seek to enhance the reputational capital of the institution, the school or degree program (such as targeted marketing campaigns, and building positive relationships with big employers in the local area). Enrolment profile enhancement strategies, such as enrolling more students in degrees for which there is known labour market demand for full-time roles, and conversely reducing enrolments in non-vocational degree programs or programs associated with poorer outcomes, is another possibility. Such enrolment profile enhancement strategies would need to be balanced carefully according to predicted labour market demand, levels of student demand for programs, and degree delivery costs. Employability Awards, the awarding of badges and micro-credentials, that emphasise participation in co-curricular activities can create positional advantage in the graduate jobs market and also enhance short-term outcomes.

In terms of degree offerings, one strategy involves narrowing of curriculum to educate graduates for specific jobs and emphasise the development of desired professional capabilities for those roles, strengthening the 'vocationalisation' of curriculum (Boden \& Nedeva, 2010). Curriculum narrowing and a decline in liberal arts / humanities and general 
science degrees is also driven by student demand for degrees with clear career pathways and good graduate outcomes. Somewhat ironically, an emphasis on the development of specific job skills over broader capabilities may in some instances militate against the university's role in preparing graduates for a dynamic labour market and contribution to the knowledge economy (Lyons \& Hil, 2015). This tension is discussed further in later sections of this article.

Social capital-based strategies may also be effective in achieving positive short-term graduate outcomes (Jackson, 2014). Work integrated learning and industry mentoring schemes build students' employability skills and knowledge, and also develop professional relationships that can lead to the acquisition of work in the short term (Bridgstock, 2019). Other short-term strategies aim to enhance students' abilities to find and acquire work, through learning how to write job applications and resumes, and how to perform well in job interviews, a sub-category of carer development learning / career self-management learning (Bridgstock, 2009).

\section{Employability as readiness to enter a profession}

The second way that universities engage with graduate employability is through preparing students to enter a profession, through professionally accredited degree pathways (Bravenboer \& Lester, 2016). The formal accreditation indicates that the program's graduates are deemed to possess the capabilities required to progress toward registration in, or recognition by, that profession (Harvey, 2004). During the process of professional accreditation, a degree program is assessed against predetermined criteria within various categories (such as its learning objectives, curriculum content, learning activities such as placements and internships, support and resourcing, and teaching staff profile). Professional accreditation can be categorised as 'regulated' or 'non-regulated'. Regulation is enforced by 
government on behalf of the public in professions where public safety needs to be ensured. In Australia, professions such as nursing, medicine, architecture and psychology are regulated, whereas engineering, accountancy and journalism are unregulated, but are still accredited by their respective professional bodies.

Degree accreditation is most strongly associated with priorities around external quality assurance, and consistency of learning within programs. However, in Harvey's (2004) study of the perceptions of academics and university managers relating to accreditation, a strong employability theme also emerged. Participants discussed professional accreditation as either entirely necessary for professional employment in the field, or at least that it enhanced the prospects of their graduates for professional employment. Participants were also concerned that failure to achieve accreditation status would reduce both the employability outcomes and also the marketability and competitiveness of their degree programs.

In degree programs with external accreditation, tensions may exist between accreditation requirements and university curriculum requirements, such as the integration of university graduate attributes, and wider career development learning. The curriculum in many professionally accredited programs can be truly 'crowded' with occupational requirements for professional competence impeding the inclusion of wider capability development (Mills et. al., 2018; Reid, 2016), which may also militate against the inclusion of wider strategies for enhancement of employability, such as integration of career development learning.

That professional degree programs should have requirements that assure the quality and safe practice of commencing professionals, and in turn that students of professional degrees may expect to acquire the capabilities and recognition that will support them to embark on professional careers, seems appropriate. However, professional accreditation has been argued to run the risk of overemphasis on specific and short-term professional needs 
rather than longer term outcomes (Masse \& Popovitch, 2007; Vibert, 2018). There is also wide variation in the extent to which accrediting bodies encourage innovation in degree programs, versus policing compliance with current standards and requirements.

The largest cause for concern with professionally accredited programs and employability lies not with the preparation of students for their intended profession, but rather in the extent to which a proportion of these students will not ever practice in these professions, or will only remain in them for a short while, and therefore wider career and employability learning may be strongly beneficial as they move into different life and career pathways. Examination of graduate destinations from professional programs suggests that graduates end up pursuing a wider variety of pathways than often considered by universities or the students themselves. For instance, up 50 per cent of new Australian teachers leave the profession within five years (Gallant \& Riley, 2014); a recent study of law graduates suggests that only two-thirds commence their careers in law, with the rest employed across other professional employment (Melbourne Law School, 2017). Even when graduates stay in their professional fields, a more flexible degree program may help them identify and pursue career opportunities that may not otherwise have been considered, such as pursuit of a specialisation or new/emerging sub-field.

\section{Employability as living and working productively and meaningfully across the lifespan}

The third sense of graduate employability is far less well-bounded than the other two. It relates to the role of higher education in developing a graduate's ongoing capacity to live, work and otherwise contribute to society and the economy productively and meaningfully throughout life, referred to hereafter as the lifelong/lifewide approach to employability (see also Bridgstock \& Tippett, 2019; Fullan, 1993). Employability in this sense is the capacity to employ or use one's capabilities in ways that are personally meaningful and appropriate, and 
contribute to the contexts with which the graduate interacts. That is, graduate employability could be thought of as the ability to harness one's capabilities in order to add value across a range of different contexts across the life course, including social and civic engagement, and economically and socially through one's work and career. This sense captures the graduate's own aims and goals, and their life and work circumstances.

For instance, while the majority of graduates aspire to a professional career after they graduate, some may wish to contribute to an area of knowledge or practice; some need to balance work and non-work activity; and some students enrol in university intrinsically motivated to learn without specific career outcomes in mind (Guiffrida et.al., 2013). These motivations may overlap, and they will certainly change over the lifespan as the graduate's circumstances change. Equally, for some graduates, full-time employment may never be a possibility due to cultural expectations, disability/health conditions or family responsibilities, or indeed labour market conditions in different regions or industries, but this view of graduate employability recognises a wide variety of life circumstances and ways that graduates can, and do, add value.

The graduate employability agenda has been variously criticised and resisted by some academics (e.g., Grant-Smith \& Osborne, 2017) for 'neoliberalising' education, threatening academic freedom, and dumbing down / reducing the capacity of higher education to foster critical capabilities and thinking. A broader conceptualisation of graduate employability as explored here may be more congruent with long-held university values around wider contributions to economy and society, recently reinvigorated in Barnett's $(2011,2017)$ concept of the 'ecological university'. Barnett argues that the university is interconnected with seven ecosystems in which it is embedded: knowledge; social institutions (including politics); physical environment; economy; culture; learning; and human subjectivity. The university is influenced by, and in turn intentionally acts upon, the seven zones which are not 
separate from the ecological university, but that they all flow into one another. He further suggests that even now when universities maintain some level of perceived independence from their ecosystems, that these still form a 'deep ecology' of the university that can be brought to the surface and strengthened through visioning and strategy.

The wider lifelong/lifewide notion of graduate employability therefore gives credence to the development of a wider and deeper set of graduate capabilities than either the professional readiness or short-term outcomes notions imply -- although it might be argued to encompass them. The lifespan approach to employability can be linked with Holmes' (2001) arguments that employability should move beyond the 'possessional' (meaning the possession of skills and knowledge that are useful for acquisition of, and performance at, work) to a 'processual' approach involving ongoing sensemaking, self-discovery and selfconstruction (Savickas, 2011). Advocates of processual perspectives on employability emphasise identity as a central construct, with individuals progressively constructing and refining their career and life identities through authentic experiences and social interactions (Bridgstock et. al., 2019; Jackson, 2016; Tomlinson, 2017). In turn, identity and 'who I am/ who I will be' frames decisions and action, becoming something of a 'cognitive compass' (Fugate et. al., 2004), supporting learning and career choices, and helping people to make sense of learning experiences.

The lifelong/lifewide notion of graduate employability can thus also be seen to support the optimisation of economic contributions of graduates, in part through graduate employment, but also through other considered economic activity. Through learning to make informed decisions through an ongoing process of identity development and career selfmanagement (Bridgstock 2009; Bridgstock et al., in press) which optimises the match between individual motivations, needs and circumstances on the one hand, and opportunities to add value (such as through employment) on the other, graduates can arguably become 
better equipped to contribute economically both now, and in an ongoing way throughout their lives.

Processually (rather than possessionally) orientated employability learning seems even more important now because of changes to the world of work and society that are already underway under the disruptive influence of digital technologies, and are predicted to gather momentum over the next few decades (CEDA, 2015). While commentators agree that human capabilities relating to creativity and connection with others will continue to be valued, and that new job roles and other ways to add value will emerge, other roles and opportunities are already disappearing. Predictions of the individual and social effects of these changes range from the optimistic to the calamitous, but what is widely agreed is that change will continue to occur, and that people will need to continually adapt and reskill. In turn, the ability and propensity to career self-manage in an ongoing way will underpin effective adaptation and learning.

The lifelong/lifewide perspective is not without challenges. We are in an era where universities are increasingly tasked with demonstrating institutional performance, and where a key element of this is demonstrating the value that graduates add through work. A conceptualisation of employability that recognises and promotes a multiplicity of student circumstances, aims and potential outcomes over an extended and unspecified period, does not lend itself to easy measurement. It is somewhat unclear what institutional success in a lifelong/lifewide sense might look like (although for a discussion of what wider subjective measures and measures of graduate value might entail, see Jackson \& Bridgstock, 2018). Because direct impact of a lifelong/lifewide employability strategy can be hard to demonstrate, it can be difficult to argue for more explicit embedding of such approaches into institutional or government policy. 
A lifelong/lifewide perspective might also result in diffusion of curriculum. Rather than a 'narrowing' of curriculum, per the discussion of professional readiness covered previously in this article, a lifelong/lifewide approach could encourage learners to want to pursue a very wide range of learning pathways and opportunities that a traditionally constituted degree curriculum may not be able to support. In some ways, a 'just for you learning' model, where students create their own degree programs through micro certifications - captured in EY's (2018) visualisation of the 'disruptor university' in future higher education - might better address these potentially very diverse learning requirements. The question then becomes how to support learners to construct these micro learning experiences into a coherent and progressive learning journey.

\section{Navigating a strategic path}

It can be seen that the three views of graduate employability can be highly complementary to one another, but tensions do emerge. For instance, one might expect that a professional readiness approach would lead to better short-term graduate outcomes. However, in some cases professionally accredited or recognised undergraduate degrees do not lead directly to professional work, but rather depend on further postgraduate study, for which there are further academic and other entry hurdles. Australian degrees in psychology and architecture are good examples of this (Architects Accreditation Council of Australia, 2019; Australian Psychology Registration Council, 2019). Graduates who complete the first degree but do not meet the requirements for the corresponding postgraduate program are then challenged to reframe their identities away from the narrow professional outcomes of their undergraduate program, and to acquire additional capabilities for the new trajectories that they must choose. To do this requires effective career self-management, drawn from the lifelong/lifewide sense of graduate employability.

The different views of graduate employability can lend themselves to the adoption of different specific strategies and approaches, and this is where, in the context of limited 
curricular space, competition between the views becomes a potential challenge. Table 1 presents the foci of capability development and specific strategies and approaches for each view. It can be argued that some strategies and approaches foster employability across multiple views. One key example of an approach that potentially cuts across the three views is work integrated learning, which can concurrently foster the development of career identity, while developing students' professional capabilities and enhancing their social and cultural capital for short term employment (Jackson, 2017). However, some strategies and approaches are highly view-specific, such as employability awards, which aim to promote short-term outcomes of graduates by recognising and promoting co- and extra-curricular experiences and skills ${ }^{1}$.

[Table 1 near here]

Acknowledging that universities necessarily maintain concurrent commitments to all three views of graduate employability, this article seeks to promote a pragmatic institutional approach that balances the views and their associated strategies and initiatives. While literature that documents institutional approaches to graduate employability does exist (e.g., Bennett et. al., 2017; Farenga \& Quinlan, 2015), there appears to be remarkably little explicit differentiation by desired outcomes, either in the literature or the institutional strategies themselves.

A logical step in programmatic employability strategy would be to clarify the desired balance between desired outcomes for each program, bearing in mind the overall constraint of limited curricular and co-curricular space associated with a single degree. The chosen balance should also be communicated clearly to students, so that they can make informed enrolment decisions in the light of their particular learning needs. Once the balance has been

\footnotetext{
${ }^{1}$ It should be noted that some Employability Awards encourage students to reflect upon their learning experiences and learn how to articulate their value. Learning how to do this could be thought of as a lifelong/lifewide strategy
} 
determined, specific strategies and approaches in accordance with this can be included in the program design in a deliberate way.

It is suggested that initial undergraduate degrees contain lifelong/lifewide elements, even if they are accredited programs that emphasise professional readiness. The inclusion of some broader experiences, identity and career development will advantage learners within their chosen professions and will assist them to obtain initial employment, as well as enabling them to realise wider and deeper outcomes. Subsequent educational experiences and credentials can shift focus towards professional capabilities and specific desired employment outcomes.

\section{Conclusion}

By unpacking and exploring the three views of graduate employability, this article has drawn attention to the obvious but often unstated fact that employability development cannot adequately be addressed in a single undergraduate degree program. In terms of initial degree experiences, the Bologna model of a 'breadth' undergraduate degree followed by a professionally-focussed postgraduate program at advanced level could be more congenial to accommodation of different employability aims than a traditional 3-year degree. However, in a context where degrees are increasingly expensive and students are motivated to move into the workforce as soon as possible, this model may not be realistic for all. Certainly, it is incumbent upon higher education to move away from a culture of single terminal degrees, to provide responsive professional and socially orientated learning experiences that meet learners' ongoing needs to refocus, retrain, and reskill, in the context of an ever-changing changing society and world of work. 


\section{References}

Architects Accreditation Council of Australia. (2019). Pathways to registration as an architect in Australia. Retrieved from https://www.aaca.org.au/registration-as-an$\underline{\operatorname{architect/}}$

Australian Psychology Registration Council. (2019). APAC-Accredited psychology programs. Retrieved from

https://www.psychologycouncil.org.au/APAC accredited psychology programs austr $\underline{\text { alasia }}$

Bennett, D., Knight, E. B., Divan, A., Kuchel, L., Horn, J., van Reyk, D., \& Burke da Silva, K. (2017). How do research-intensive universities portray employability strategies? A review of their websites. Australian Journal of Career Development, 26(2), 52-61.

Farenga, S., \& Quinlan, K. (2016). Classifying university employability strategies: Three case studies and implications for practice and research. Journal of Education and Work, 29(7), 767-787.

Bakhshi, H., Downing, J. M., Osborne, M. A., \& Schneider, P. (2017). The future of skills: employment in 2030. London, UK, NESTA and Pearson.

Barnett, R. (2011). The coming of the ecological university. Oxford Review of Education, 37(4), 439-455.

Barnett, R. (2017). The ecological university: A feasible utopia. London, UK, Routledge.

Barrie, S. C. (2007). A conceptual framework for the teaching and learning of generic graduate attributes. Studies in Higher Education, 32(4), 439-458.

Becker, G. (1964). Human Capital. Chicago: University of Chicago Press.

Boden, R., \& Nedeva, M. (2010). Employing discourse: universities and graduate ‘employability'. Journal of Education Policy, 25(1), 37-54. 
Bravenboer, D., \& Lester, S. (2016). Towards an integrated approach to the recognition of professional competence and academic learning. Education + Training, 58(4), 409-421.

Bridgstock, R. (2009). The graduate attributes we've overlooked: Enhancing graduate employability through career management skills. Higher Education Research and Development, 28(1), 31-44.

Bridgstock, R. (2018) Graduate Employability 2.0: Learning for life and work in a socially networked world. In J. Higgs, W. Letts, \& G. Crisp (Eds.) Education for Employability: Learning for Future Possibilities. Rotterdam, The Netherlands, Sense-Brill Publishers. Bridgstock, R., Grant-Iramu, M., \& McAlpine, A. (in press). Integrating career development learning into the curriculum: Collaboration with the careers service for employability. Journal of Teaching and Learning for Graduate Employability.

Bridgstock, R., Grant-Iramu, M., Bilsland, C., Tofa, M., Lloyd, K., \& Jackson, D. (in press). Going beyond 'getting a job': Graduates' narratives and lived experiences of employability and their career development. In J. Higgs, W. Letts, \& G. Crisp (Eds.), Education for employability II: Learning for future possibilities. Rotterdam, The Netherlands, Sense-Brill.

Bridgstock, R., \& Tippett, N. (eds.) (2019). Higher Education and the Future of Graduate Employability: A Connectedness Learning Approach. London, UK, Edward Elgar.

Brown, P., Hesketh, A., \& Williams, S. (2004). The mismanagement of talent: Employability and jobs in the knowledge economy. Oxford, UK, Oxford University Press.

Clanchy, J., \& Ballard, B. (1995). Generic skills in the context of higher education. Higher Education Research and Development, 14(2), 155-166

Clark, H.F. 1930. Economic effects of education. The Journal of Higher Education, 1(3), 141-148. 
Committee for Economic Development of Australia (2015). Australia's future workforce? Melbourne, Australia, CEDA.

EY (2018). Can the universities of today lead learning for tomorrow. Sydney, Australia, EY.

Farenga, S. A., \& Quinlan, K. M. (2016). Classifying university employability strategies:

Three case studies and implications for practice and research. Journal of Education and Work, 29(7), 767-787.

Foundation for Young Australians (2018). The new work reality. Melbourne, Australia, FYA.

Fugate, M., Kinicki, A. J., \& Ashforth, B. E. (2004). Employability: A psycho-social construct, its dimensions, and applications. Journal of Vocational Behavior, 65(1), 14-38.

Fullan, M. G. (1993). Why teachers must become change agents. Educational Leadership, 50, $12-12$.

Gallant, A., \& Riley, P. (2014). Early career teacher attrition: New thoughts on an intractable problem. Teacher Development, 18(4), 562-580.

Grant-Smith, D., \& Osborne, N. (2017). Resisting the 'employability' doctrine through anarchist pedagogies and prefiguration. Australian Universities' Review, 59(2), 59-69.

Guiffrida, D. A., Lynch, M. F., Wall, A. F., \& Abel, D. S. (2013). Do reasons for attending college affect academic outcomes? A test of a motivational model from a selfdetermination theory perspective. Journal of College Student Development, 54(2), 121-139.

Harvey, L. (2004). The power of accreditation: views of academics. Journal of Higher Education Policy and Management, 26(2), 207-223.

Hazelkorn, E. (2015). Rankings and the reshaping of higher education: The battle for worldclass excellence. Basingstoke, UK, Palgrave-Macmillan.

Higher Education Statistics Agency (2018). Graduate Outcomes survey questions. Cheltenham, UK, HESA. 
Hillage, J., \& Pollard, E. (1998). Employability: developing a framework for policy analysis. London, UK, Department of Education and Employment.

Holmes, L. (2001). Reconsidering Graduate Employability: The 'graduate identity' approach. Quality in Higher Education, 7(2), 111-119.

Jackson, D. (2014). Factors influencing job attainment in recent Bachelor graduates: Evidence from Australia. Higher Education, 68(1), 135-153.

Jackson, D. (2016). Re-conceptualising graduate employability: the importance of preprofessional identity. Higher Education Research \& Development, 35(5), 925-939. Jackson, D. (2017). Developing pre-professional identity in undergraduates through workintegrated learning. Higher Education, 74(5), 833-853.

Jackson, D \& Bridgstock, R. (2018). Evidencing student success and graduate employability in the contemporary world-of-work: renewing our thinking. Higher Education Research and Development, 37(5), 984-998.

Jackson, D., Bridgstock, R. (in-press). Evidencing student success and career outcomes among Business and Creative Industries graduates. Higher Education Policy and Management.

Kalfa, S., \& Taksa, L. (2015). Cultural capital in business higher education: reconsidering the graduate attributes movement and the focus on employability. Studies in Higher Education, 40(4), 580-595.

Karmel, T., \& Carroll, D. (2016). Has the graduate job market been swamped? NILS working paper series No.228/2016. Adelaide, SA, National Institute of Labour Studies, Flinders University.

Lyons, K., \& Hil, R. (2015). A shift towards industry-relevant degrees isn't helping students get jobs. Chain Reaction, 125, 18-19. 
Masse, M. H., \& Popovich, M. N. (2007). Accredited and non-accredited media writing programs are stagnant, resistant to curricular reform, and similar. Journalism \& Mass Communication Educator, 62(2), 141-160.

McQuaid, R. W., \& Lindsay, C. (2005). The concept of employability. Urban Studies, 42(2), 197-219.

Melbourne Law School. (2017). Career outcomes. Retrieved 19 December 2018 from https://aw.unimelb.edu.au/students/career-services/career-outcomes

Mills, A., Sanders, A. K., \& Hussain, S. S. (2018). Fitting it all in? A census of undergraduate ethics and leadership courses in accredited US journalism and mass communication programs. Journalism \& Mass Communication Educator, 1-11.

Piperopoulos, P. (2012). Entrepreneurship, Innovation and Business Clusters. London, UK, Routledge.

Reid, C. T. (2016). Education for sustainable development and the professional curriculum. The Law Teacher, 50(3), 300-306.

Savickas, M. L. (2011). Constructing careers: Actor, agent, and author. Journal of Employment Counseling, 48(4), 179-181.

Schulte, P. (2004). The entrepreneurial university: A strategy for institutional development. Higher Education in Europe, 29(2), 187-191.

Smith, M., Bell, K., Bennett, D., \& McAlpine, A. (2018). Employability in a global context: Evolving policy and practice in employability, work integrated learning, and career development learning. Wollongong, Australia, Graduate Careers Australia.

Social Research Centre (2019a). 2018 graduate outcomes survey. Melbourne, Australia, Social Research Centre.

Social Research Centre (2019b). 2018 graduate outcomes survey - longitudinal (GOS-L). Melbourne, Australia, Social Research Centre. 
Stevenson, J., Clegg, S., \& Lefever, R. (2010). The discourse of widening participation and its critics: An institutional case study. London Review of Education, 8(2), 105-115.

Tomlinson, M. (2007). Graduate employability and student attitudes and orientations to the labour market. Journal of Education and Work, 20(4), 285-304.

Tomlinson, M. (2017). Introduction: graduate employability in context: Charting a complex, contested and multi-faceted policy and research field. In M. Tomlinson \& L. Holmes (Eds), Graduate Employability in Context, 1-40. London, UK, Palgrave Macmillan.

Vibert, J. (2018). The evolving context of quality assurance: A perspective from specialized and professional accreditation. In S. Phillips, \& K. Kinser (Eds.), Accreditation on the edge: Challenging quality assurance in higher education. Baltimore, USA, JHU Press.

Yorke, M., \& Harvey, L. (2005). Graduate attributes and their development. New Directions for Institutional Research, 2005(128), 41-58. 
Table 1. Views of graduate employability by focus of capability development, strategies and approaches

\begin{tabular}{|c|c|c|c|}
\hline & $\begin{array}{l}\text { Short term } \\
\text { employment }\end{array}$ & $\begin{array}{l}\text { Professional } \\
\text { readiness }\end{array}$ & Lifelong/lifewide \\
\hline \multirow[t]{2}{*}{$\begin{array}{l}\text { Focus of } \\
\text { capability } \\
\text { development }\end{array}$} & $\begin{array}{l}\text { Capabilities for } \\
\text { securing employment }\end{array}$ & $\begin{array}{l}\text { Capabilities for } \\
\text { professional } \\
\text { competence }\end{array}$ & $\begin{array}{l}\text { Capabilities for a wide } \\
\text { range of motivations } \\
\text { and contributions to } \\
\text { economy and society }\end{array}$ \\
\hline & Capabilities for now & $\begin{array}{l}\text { Capabilities for now } \\
\text { (extent of future- } \\
\text { focus depends on } \\
\text { professional } \\
\text { accrediting body, if } \\
\text { applicable) }\end{array}$ & $\begin{array}{l}\text { Capabilities for now } \\
\text { and the future }\end{array}$ \\
\hline \multirow[t]{5}{*}{$\begin{array}{l}\text { Specific } \\
\text { strategies and } \\
\text { approaches }\end{array}$} & $\begin{array}{l}\text { Labour market } \\
\text { interventions } \\
\text { Job search and } \\
\text { acquisition capability } \\
\text { development and } \\
\text { support }\end{array}$ & $\begin{array}{l}\text { Disciplinary and } \\
\text { professional } \\
\text { capability } \\
\text { development }\end{array}$ & $\begin{array}{l}\text { Career development } \\
\text { learning, career } \\
\text { management and } \\
\text { identity development } \\
\text { through experiences } \\
\text { and social interactions }\end{array}$ \\
\hline & $\begin{array}{l}\text { Institutional } \\
\text { reputation } \\
\text { enhancement }\end{array}$ & & $\begin{array}{l}\text { Enterprise and } \\
\text { entrepreneurship } \\
\text { learning }\end{array}$ \\
\hline & $\begin{array}{l}\text { Social capital and } \\
\text { networking } \\
\text { approaches }\end{array}$ & & \\
\hline & $\begin{array}{l}\text { Employability } \\
\text { awards }^{1}\end{array}$ & & \\
\hline & $\begin{array}{l}\text { Transferable } \\
\text { capability } \\
\text { development }\end{array}$ & & \\
\hline
\end{tabular}

\footnotetext{
${ }^{1}$ It should be noted that some employability awards encourage students to reflect upon their learning experiences and learn how to articulate their value. Learning how to do this could be thought of as a lifelong/lifewide strategy
} 